\section{'UF-1013-1': An Infertile Cultivar of Lantana camara}

Zhanao Deng

Institute of Food and Agricultural Sciences, Environmental Horticulture Department, Gulf Coast Research and Education Center, University of Florida, 14625 County Road 672, Wimauma, FL 33598

Sandra B. Wilson

Environmental Horticulture Department, University of Florida, P.O. Box 110675, Gainesville, FL 32611

Xiaobao Ying
Institute of Food and Agricultural Sciences, Environmental Horticulture
Department, Gulf Coast Research and Education Center, University of
Florida, 14625 County Road 672, Wimauma, FL 33598

Chunxian Chen

U.S. Department of Agriculture, Agricultural Research Service, Fruit and Tree Nut Research Laboratory, 21 Dunbar Road, Byron, GA 31008

Rosanna Freyre and Victor Zayas

Environmental Horticulture Department, University of Florida, P.O. Box 110675, Gainesville, FL 32611

David M. Czarnecki II

Institute of Food and Agricultural Sciences, Environmental Horticulture Department, Gulf Coast Research and Education Center, University of Florida, 14625 County Road 672, Wimauma, FL 33598

Additional index words. cultivar, invasive, lantana, noninvasive, sterile, triploid

Received for publication 4 Feb. 2020. Accepted for publication 5 Mar. 2020.

Published online 6 May 2020.

The development and evaluation of 'UF-1013-1' were funded in part by the U.S. Department of Agriculture (USDA) hatch projects (project nos. FLA-GCR-005065 and FLA-GCC-005507), the USDA/Tropical and Subtropical Agriculture Research (TSTAR) program, and the Florida Department of Agriculture and Consumer Service Specialty Crop Block Grant program.

We thank Gail Bowman, Keri Druffel, Mary Derrick, Patricia Frey, and Joyce Jones for their technical assistance. We are grateful to Dr. Jaroslav Doležel (Laboratory of Molecular Cytogenetics and Cytometry, Institute of Experimental Botany, Olomouc, Czech Republic) who provided pea seeds that were used as the internal standards in the flow cytometry analysis. We thank the Proven Winners North America, LLC, and Riverview Flower Farms, Inc., for trialing 'UF-1013-1' and sharing some of their observations, seed count data, and photos. We are also grateful to Mr. Hugh Gramling for his inspiration and support of our effort in genetic sterilization of lantana.

D.M.C. is a former graduate student at the University of Florida. Current affiliation: Ernst Benary of America, Inc., 195 Paulsen Road, Watsonville, CA 95076.

Z.D. is the corresponding author. E-mail: zdeng@ ufl.edu.

This is an open access article distributed under the CC BY-NC-ND license (https://creativecommons. org/licenses/by-nc-nd/4.0/).
Lantana (Lantana L., Verbenaceae) is produced and grown as an ornamental plant in the United States and many other countries in the world. The ornamental value of lantana comes from its bright-colored flowers. Other attributes of this plant include attraction to multiple species of butterflies; tolerance of drought, heat, and salt; low maintenance requirements; and 2004). With these attributes, lantana is commonly used in the landscape and gardens, including butterfly gardens and water-saving xeriscaping gardens. Propagation and production of lantana plants have been a significant component of the environmental horticulture industry in a number of countries in the world and multiple states in the United States. For example, a survey of the Florida nursery industry indicated that $19 \%$ of the responding nurseries produced lantana and the annual sales value of lantana in Florida was at more than $\$ 40$ million (Wirth et al., 2004).

The majority of lantana plants in commercial production and landscape use belongs to Lantana camara L. This species is native to Central and South America, including the West Indies (Sanders, 2001) and was introduced to the United States in the 1800s (Swearingen and Bargeron, 2016). Since then, L. camara has escaped cultivation and become naturalized in 13 states in the United States (Swearingen and Bargeron, 2016). In Florida, escaped L. camara has hybridized ease of propagation (Bachman, 2018; Schoellhorn, with Lantana depressa Small, endangering this native species (FLEPPC, 2019; Hammer, 2004; Sanders, 1987). Lantana camara has been listed as a Category I invasive species in Florida by the Florida Exotic Pest Plant Council (FLEPPC, 2019). The University of Florida Institute of Food and Agricultural Sciences (UF/IFAS) Assessment of NonNative Plants in Florida's Natural Areas concluded that invasive $L$. camara is not to be recommended for production or landscape use in south, central, and north Florida (http:// assessment.ifas.ufl.edu/). The assessment was based on data collected from escaped, naturalized L. camara. The Georgia Exotic Pest Plant Council (GA-EPPC, 2019) listed L. camara as a Category 3 exotic plant, which is a minor problem in Georgia natural areas, or is not yet known to be a problem in Georgia but is known to be problem in adjacent states (GA-EPPC, 2019).

A research program was initiated in 2004 at UF/IFAS's Gulf Coast Research and Education Center (GCREC) to identify and develop infertile $L$. camara cultivars. The majority of commercial L. camara cultivars were found to be fertile (Czarnecki, 2011). New infertile cultivars are needed by the environmental horticulture industry and for protecting native species and the environment (Bechtloff et al., 2019). In 2016, we released two infertile triploid lantana cultivars, UF-1013A-2A (Bloomify Red) and UF1011-2 (Bloomify Rose) (Deng et al., 2017). They performed well in variety trials (Bachman, 2018) and are well received by nursery growers.

'UF-1013-1' (Figs. 1 and 2) is a sibling of 'Bloomify Red' and shares the high level of male and female infertility and superior plant performance with 'Bloomify Red', but 'UF1013-1' has shorter plants, larger flowers, a higher nuclear DNA content, and a different molecular marker profile. On the basis of the high level of male and female infertility of 'UF-1013-1' and its lack of hybridization potential with $L$. depressa, an Infraspecific Taxon Protocol request was submitted to the UF/IFAS Invasive Plants Working Group,

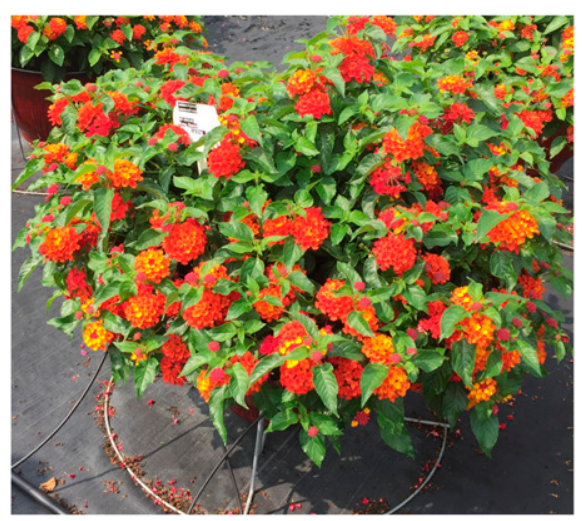

Fig. 1. Plant $(\approx 11$ weeks old) and flowers of 'UF1013-1' lantana (L. camara) in a container trial in Michigan (from Mr. K. Hurd, Proven Winners). 
and the Working Group unanimously approved the release of 'UF-1013-1' as a new sterile cultivar.

\section{Origin}

'UF-1013-1' resulted from a cross between breeding line DROP-25 and 'Landmark Flame Improved'. The cross was made in Fall 2010 at the GCREC, and the cultivar was initially selected as an individual plant in April 2012. The intellectual property status of 'Landscape Flame Improved' is unclear. Google searches linked this cultivar to one cultivar called Balandimfla, but it was not found in the USPTO database. 'UF-1013-1' has been asexually propagated by cuttings for

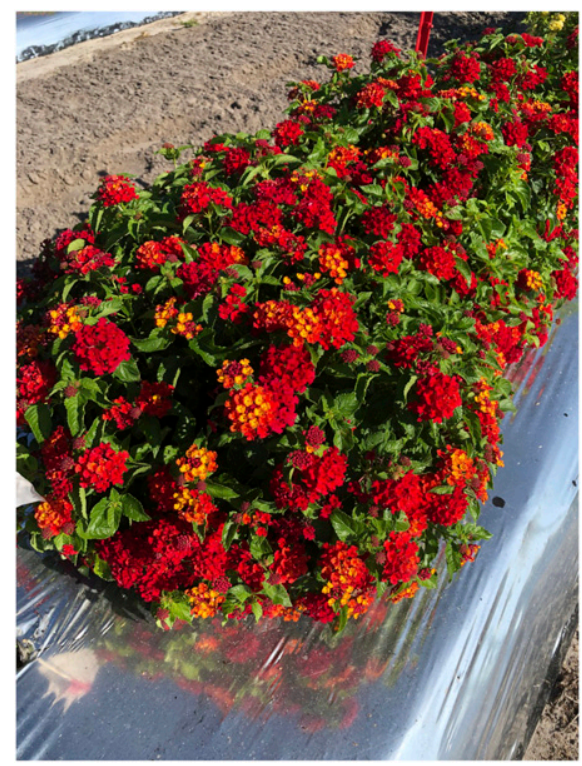

Fig. 2. Plants of 'UF-1013-1' lantana (L. camara) grown on a mulched ground bed in Citra, $\mathrm{FL}$, in full sun (May 2019). at least six generations, and its characteristics are stable and consistent.

\section{Description}

Description of color for plant parts were based on comparison with the Royal Horticultural Society Color Chart (Royal Horticultural Society, 1986). Plants used for describing color and other attributes were propagated from rooted cuttings and grown outdoors in 11.4-cm pots in the shade house in Balm, FL, for 11 to 16 weeks.

Plants of 'UF-1013-1' are multistemmed shrubs, with a mounding growth habit, $\approx 36$ $\mathrm{cm}$ wide and $25 \mathrm{~cm}$ tall. Young stems are yellow-green [Royal Horticultural Society (RHS) 144B], square, semiwoody, and covered with soft hairs (scabrous) but no prickles; old stems are round, light brown (RHS 199A/B), and smooth, with few hairs. Leaves are opposite, simple, with petioles 1.4 to $2.7 \mathrm{~cm}$ long and in yellow-green (close to RHS 146C). Mature leaf blades are ovate, 5.2 to $9.4 \mathrm{~cm}$ long, 3.1 to $6.2 \mathrm{~cm}$ wide, with serrated margins and an average of 39 teeth per leaf, an obtuse to broadly truncated base, and an acute apex. The upper leaf surface is green (RHS 147A), covered with soft hairs. The lower surface is green (RHS 147B). Inflorescences are umbel-like, $\approx 4.5 \mathrm{~cm}$ wide across the top, bearing 22 to 30 flowers, and with yellow-green (RHS 144A) peduncles 1.4 to $3.3 \mathrm{~cm}$ long. Flowers are bright yellow (RHS 13A) when opening initially and then turn red (RHS 34A). Inflorescences rarely bear fruit.

The nuclear DNA content of 'UF-1013-1' was determined using a CyFlow Cube 6 flow cytometer (Sysmex, Partec $\mathrm{GmbH}$, Otto-Hahn-Straße 32 D-48161, Münster, Germany) and the procedure described by Doležel et al. (2007) and modified by Cao et al. (2014). Pea cultivar Ctirad (Pisum sativum) with a nuclear content of $9.09 \mathrm{pg} /$ $2 \mathrm{C}$ was selected as the internal reference for use in this study. The nuclear DNA content of lantana samples was calculated according to Doležel et al. (2007): sample nuclear DNA content $(\mathrm{pg} / 2 \mathrm{C})=$ internal reference nuclear DNA content $(9.09) \times$ (mean fluorescence value of sample / mean fluorescence value of internal reference). The ploidy level of 'UF1013-1' was determined by comparing its nuclear DNA content with the DNA content of known diploid, triploid, and tetraploid lantana cultivars. 'UF-1013-1' is a triploid with an average nuclear DNA content of 4.82 $\mathrm{pg} / 2 \mathrm{C}$ (Table 1).

'UF-1013-1' was analyzed for DNA fingerprint or molecular marker profile using three lantana-specific simple sequence repeat (SSR) primers. Lantana genomic DNA was isolated from lantana leaves at the GCREC in Balm, FL. Primers were developed as described by Gong and Deng (2011) from SSRenriched lantana genomic sequences (L. Gong and Z. Deng, unpublished data; Table 2). Polymerase chain reaction (PCR) amplification, capillary electrophoresis, and allele scoring were performed at the USDA/ ARS Fruit and Tree Nut Research Laboratory, Byron, GA, using a procedure previously described by Chen et al. (2014) with minor modifications. PCR was performed on a C1000 Touch Thermal Cycler with a CFX384 block module (BioRad, Hercules, $\mathrm{CA}$ ) in a $5-\mu \mathrm{L}$ volume consisting of $1 \times \mathrm{PCR}$ buffer, $0.2 \mathrm{~mm}$ dNTPs, $2 \mathrm{~mm} \mathrm{MgCl} 2,0.3 \mu \mathrm{M}$ of the dye-labeled forward and regular reverse primers, 0.5 units of Taq DNA polymerase (BioExpress, Kaysville, UT), and $\approx 10$ ng lantana genomic DNA. A touchdown PCR program was used, with an initial denaturation at $94{ }^{\circ} \mathrm{C}$ for $3 \mathrm{~min}$, followed by 10 cycles of denaturation at $94{ }^{\circ} \mathrm{C}$ for $30 \mathrm{~s}$, annealing at $68{ }^{\circ} \mathrm{C}$ for $30 \mathrm{~s}$ with a $0.5{ }^{\circ} \mathrm{C}$ decrease each cycle, and extension at $72{ }^{\circ} \mathrm{C}$

Table 1. Nuclear DNA content, ploidy level, and pollen stainability of lantana cultivar UF-1013-1 and two controls, 'Bloomify Red' and 'Pink Caprice', grown in Balm and Ft. Pierce, FL, in full sun in 2015.

\begin{tabular}{|c|c|c|c|c|c|c|c|}
\hline \multirow[b]{2}{*}{ Cultivars } & \multirow[b]{2}{*}{ Nuclear DNA content $\pm \mathrm{SD}(\mathrm{pg} / 2 \mathrm{C})$} & \multirow[b]{2}{*}{ Ploidy level } & \multicolumn{2}{|c|}{ Pollen grains examined (no.) } & \multicolumn{3}{|c|}{ Pollen stainability $(\%)^{z}$} \\
\hline & & & Expt. 1 & Expt. 2 & Expt. 1 & Expt. 2 & Avg \\
\hline$\overline{\mathrm{UF}-1013-1}$ & $4.82 \pm 0.11$ & $3 x$ & 1,464 & 1,840 & $2.0 \mathrm{~b}$ & $2.4 \mathrm{~b}$ & $2.2 \mathrm{~b}$ \\
\hline Bloomify Red & $4.54 \pm 0.08$ & $3 x$ & 2,122 & 1,466 & $1.5 \mathrm{~b}$ & $4.5 \mathrm{~b}$ & $3.0 \mathrm{~b}$ \\
\hline Pink Caprice & $6.25 \pm 0.17$ & $4 x$ & 1,271 & 1,094 & $70.8 \mathrm{a}$ & $75.3 \mathrm{a}$ & $73.1 \mathrm{a}$ \\
\hline
\end{tabular}

${ }^{\mathrm{z}}$ Anthers in Expt. 1 collected from plants grown in ground beds in full sun in Balm, FL; anthers in Expt. 2 collected from plants grown in field trials in Ft. Pierce, FL. Pollen stainability data were arcsine-transformed before analysis of variance was performed. Means with the same letter within the column are not significantly different by the least significant difference procedure at $P<0.05$.

Table 2. Simple sequence repeat (SSR) marker analysis of 'UF-1013-1' and 'Bloomify Red', breeding line DROP-25 (one of the parents of 'UF-1013-1' and 'Bloomify Red'), and 'Pink Caprice', an invasive type of L. camara.

\begin{tabular}{|c|c|c|c|c|c|c|c|c|c|c|c|c|}
\hline \multirow[b]{3}{*}{ Lantana cultivars $^{\mathrm{z}}$} & \multicolumn{12}{|c|}{ Amplicons (alleles) amplified by SSR markers (bps) ${ }^{\mathrm{y}}$} \\
\hline & \multicolumn{4}{|c|}{ Marker Lantana11 } & \multicolumn{6}{|c|}{ Marker Lantana12 } & \multicolumn{2}{|c|}{ Lantana20 } \\
\hline & 150 & 152 & 156 & 160 & 135 & 143 & 145 & 147 & 150 & 152 & 93 & 109 \\
\hline UF-1013-1 & & + & & + & + & + & & + & & & + & \\
\hline Bloomify Red & + & + & & + & & + & + & & & & + & \\
\hline DROP-25 & + & + & & + & + & + & + & + & & & + & + \\
\hline Pink Caprice & & + & + & + & & + & + & & + & + & + & + \\
\hline
\end{tabular}

${ }^{\mathrm{z}}$ The other parent of 'UF-1013-1' ('Landmark Flame Improved') was not available for analysis. Nucleotide sequences of the three pairs of primers are as follows: lantana11F: (M13 tail sequence)-TGCAATTGGAGGCTTTTTCT and lantana11R: AAAGCAGCTTCAAGTTTGTGC; Lantana12F: (M13 tail sequence)GGATGAGATGATAAGGTAGGGTGT and Lantana12R: TTGGTGGTGATGACTTTGATTC. Lantana20F: (M13 tail sequence)-AGAATCAGGG TTTGGGGTTG and Lantana20R: TCGTAGCCACCACTCCTCAC. The M13 tail sequence was 5'-CCCAGTCACGACGTTG-3'

+ indicates the presence of the respective alleles in the cultivars. 


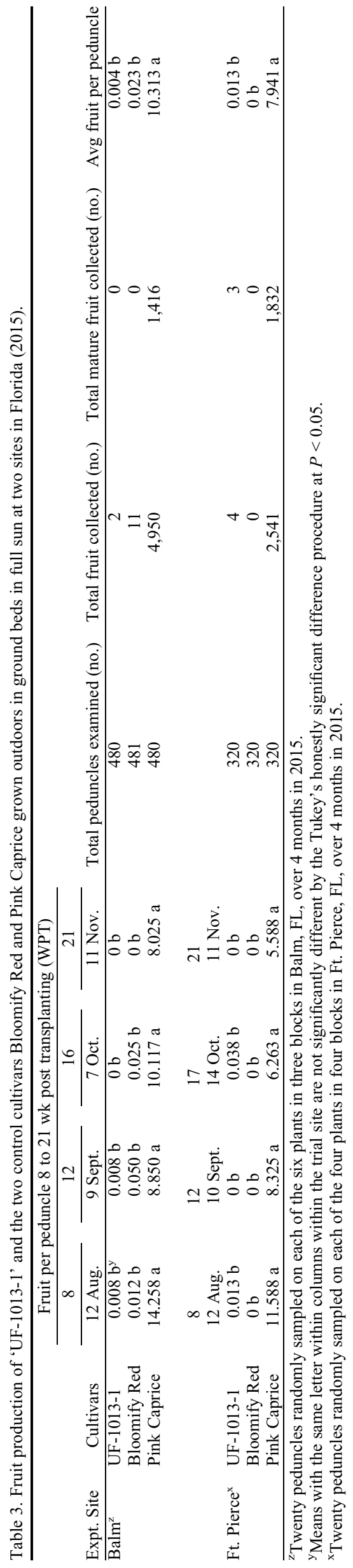

for $45 \mathrm{~s}$, followed by 25 more cycles with a constant annealing temperature at $63{ }^{\circ} \mathrm{C}$ (other parameters were the same), plus a final extension at $72{ }^{\circ} \mathrm{C}$ for $15 \mathrm{~min}$. The dye (FAM)-labeled PCR products were separated on a 3500 Genetic Analyzer (Life Technologies, Carlsbad, CA) to generate the chromatographic trace files. The SSR allele table and peak chromatograms were generated using GeneMarker 2.4 (SoftGenetics, State College, PA). In 'UF-1013-1', two major amplicons (152 and $160 \mathrm{bp}$ ) were detected with the Lantana11 marker, three major amplicons $(135,143$, and $147 \mathrm{bp})$ with the Lantana12 marker locus, and one major amplicon (93 bp) with the Lantana20 marker (Table 2). These amplicons are expected to represent the number of alleles and the status of heterozygosity at each marker locus.

In side-by-side field trials in Citra, FL, in 2018 and in greenhouse trials in Balm, FL, in 2020, plants of 'UF-1013-1' were shorter and its flower clusters were larger than its sibling cultivar Bloomify Red. 'UF-1013-1' also has $6.2 \%$ higher nuclear DNA content $(4.82 \mathrm{pg} /$ $2 \mathrm{C}$ vs. $4.54 \mathrm{pg} / 2 \mathrm{C}$ in 'Bloomify Red') (Table 1). 'UF-1013-1' carries two alleles (135 and 147 bps) at the marker Lantana12 that are absent in 'Bloomify Red' and does not carry the 150-bp allele at the Lantana11 that is present in 'Bloomify Red' (Table 2).

\section{Replicated Field Trials to Evaluate Plant Fertility and Performance}

'UF-1013-1' and 'Bloomify Red' were tested in the same replicated trials (Deng et al., 2017). As reported previously (Deng et al., 2017), the two field trials were conducted at the GCREC in Balm, FL [southwest Florida, USDA hardiness zone 9a (USDA Plant Hardiness Zone Map, 2019), and AHS heat zone 10 (AHS, 1998)], and at the Indian River Research and Education Center (IRREC) in Ft. Pierce, FL (southeast Florida, USDA hardiness zone $9 \mathrm{~b}$, and AHS heat zone 9-10). The experimental design in the Balm trial was a randomized complete block with three blocks and two plants per plot. Ground beds at the GCREC were raised $\approx 20 \mathrm{~cm}$, fumigated with Pic-Clor 60 (active ingredients 1,3-dichloropropene and chloropicrin) at $448 \mathrm{~kg}$ per hectare in Feb. 2015, and covered with white-on-black plastic. The soil was EauGallie fine sand containing $\approx 1 \%$ organic matter and a pH value between 6.2 and 7.4. The experimental design used in the $\mathrm{Ft}$. Pierce trial was a randomized complete block with four blocks and single-plant plots. Ground beds at the IRREC were not fumigated but treated with a preemergent herbicide [Sandia, 75.0\% a.i. (halosulfuronmethyl), Yuma, AZ] at a rate of $0.1056 \mathrm{~g} \cdot \mathrm{L}^{-1}$ and a $2 \%$ solution of glyphosate (Roundup WeatherMAX, 48.8\% a.i., St. Louis, MO) and covered with black groundcover. The soil was Ankona sand with $\approx 2.8 \%$ organic matter, $\mathrm{pH}$ 5.9. At each site, 'Pink Caprice' was included as a "resident species" taxon. Also at each site, 'Bloomify Red' was included as a sterile check. In addition, 21 commercial cultivars with various levels of male and female fertility were randomly placed in each block at both sites where 'UF-1013-1' and 'Bloomify Red' were evaluated.

Before installation in the field trials, plants were propagated at GCREC. Cuttings were rooted in 128-cell Speedling trays filled with a customized potting substrate. The bottom ends of cuttings were treated with Dip'n Grow (1:9 dilution, final concentration $0.1 \%$ indole-3-butyric acid and $0.05 \%$ 1-naphthaleneacetic acid) (Dip'n Grow Inc., Clackamas, OR). Rooted cuttings were pinched on 13 Mar. 2015 and transplanted on 5 May 2015 to $10.2-\mathrm{cm}$ plastic containers filled with a commercial potting mix (Fafard $3 \mathrm{~B})$ and grown in the greenhouse at GCREC (at $15{ }^{\circ} \mathrm{C} /$ night to $33{ }^{\circ} \mathrm{C} /$ day). The containergrown plants were transplanted to the ground beds in the week of 12 June 2015. Each plant was top-dressed with $\approx 15 \mathrm{~g}$ of a controlledrelease fertilizer (Osmocote; $15 \mathrm{~N}-9 \mathrm{P}_{2} \mathrm{O}_{5}$ $-12 \mathrm{~K}_{2} \mathrm{O}, 5$ to 6 months, Scotts, Marysville, $\mathrm{OH})$ and irrigated through a seep system at GCREC and through drip tapes, twice a week and $2 \mathrm{~h}$ per irrigation event, at IRREC.

\section{Pollen Stainability}

Lantana pollen stainability has been used as an indicator of lantana's male fertility (or sterility) and hybridization potential with Lantana depressa (Czarnecki, 2011; Czarnecki et al., 2012, 2014; Dehgan and Guy, 2004). Generally, triploid lantana cultivars with low pollen stainability $(<15 \%)$ have little potential to cross-pollinate $L$. depressa (Czarnecki, 2011).

Two experiments were conducted to assess the pollen stainability of 'UF-1013-1'. In Expt. 1, newly opened flowers were collected from plants grown in Balm, FL, in late July 2015, whereas in Expt. 2, flowers were collected from lantana plants grown in Ft. Pierce, FL, in mid-Aug. 2015. In both experiments, anthers were stained with $10^{-6} \mathrm{M}$ fluorescein diacetate (Sigma-Aldrich, St. Louis, MO) in $0.22 \mathrm{~m}$ sucrose at room temperature in the dark for $1 \mathrm{~h}$, as described by Czarnecki et al. (2014) and Deng et al. (2017). Plump, round pollen grains fluorescing bright yellowish green light were considered stainable, whereas misshaped, nonfluorescing, or unevenly and lightly fluorescing pollen grains were counted as nonstainable.

The number of pollen grains examined for each lantana cultivar in each staining experiment was between 1094 and 2122 (Table 1). An analysis of variance (ANOVA) and mean separation were conducted using JMP Pro 13.2.0 (SAS Institute, Cary, NC) to compare the pollen stainability of 'UF-1013-1' with that of 'Bloomify Red' and 'Pink Caprice'. The average pollen stainability of 'UF-10131 ' was $2.2 \%$ (Table 1 ), comparable to the average pollen stainability of the previously released sterile cultivar Bloomify Red. The average pollen stainability of 'Pink Caprice' was $73.1 \%$. These results indicate that 
Table 4. Plant height, width, and size index of 'UF-1013-1' compared with 'Bloomify Red' and 'Pink Caprice' grown in Florida in ground beds and full sun.

\begin{tabular}{|c|c|c|c|c|c|c|c|}
\hline \multirow[b]{2}{*}{ Trial site } & \multirow[b]{2}{*}{ Cultivar } & \multicolumn{2}{|c|}{ Plant ht $(\mathrm{cm})^{2}$} & \multicolumn{2}{|c|}{ Plant width $(\mathrm{cm})^{z}$} & \multicolumn{2}{|c|}{ Plant size inde $x^{z}$} \\
\hline & & $2 \mathrm{MPT}$ & $5 \mathrm{MPT}$ & $2 \mathrm{MPT}$ & $5 \mathrm{MPT}$ & $2 \mathrm{MPT}$ & $5 \mathrm{MPT}$ \\
\hline \multirow{2}{*}{$\overline{\text { Balm }}$} & Bloomify Red & $42.3 \mathrm{~b}$ & $53.7 \mathrm{~b}$ & $51.7 \mathrm{~b}$ & $90.2 \mathrm{~b}$ & $0.092 \mathrm{~b}$ & $0.353 \mathrm{~b}$ \\
\hline & Pink Caprice & $59.5 \mathrm{a}$ & $89.3 \mathrm{a}$ & $103.0 \mathrm{a}$ & $211.7 \mathrm{a}$ & $0.491 \mathrm{a}$ & $3.168 \mathrm{a}$ \\
\hline \multirow{2}{*}{ Ft. Pierce } & Bloomify Red & $36.3 \mathrm{~b}$ & $42.0 \mathrm{~b}$ & $35.8 \mathrm{~b}$ & $76.5 \mathrm{~b}$ & $0.049 \mathrm{~b}$ & $0.212 \mathrm{~b}$ \\
\hline & Pink Caprice & $57.0 \mathrm{a}$ & $92.5 \mathrm{a}$ & $110.5 \mathrm{a}$ & $215.3 \mathrm{a}$ & $0.551 \mathrm{a}$ & $3.406 \mathrm{a}$ \\
\hline
\end{tabular}

${ }^{\mathrm{z}}$ Plant height measured from the ground level to the highest point of the plant; plant width measured in two perpendicular directions and the average of the two widths reported. Plant size index (cubic meters) calculated using the following formula: size index $=$ plant height $(\mathrm{cm}) \times \pi \times[\mathrm{plant} \text { width }(\mathrm{cm}) / 2)^{2} / 1,000,000$, where $\pi=3.14$. 2 or 5 MPT $=2$ or 5 months posttransplant.

${ }^{\mathrm{y}}$ Means with the same letter within columns within the trial sites are not significantly different by the Tukey's honestly significant difference procedure at $P<0.05$.

Table 5. Plant and flower intensity ratings of 'UF-1013-1' compared with 'Bloomify Red' and 'Pink Caprice' grown at the Gulf Coast Research and Education Center) in Balm, FL, and at the Indian River Research and Education Center in Fort Pierce, FL, in ground beds in full sun in Aug. through Nov. 2015.

\begin{tabular}{|c|c|c|c|c|c|c|c|c|c|}
\hline \multirow[b]{2}{*}{ Trial site } & \multirow[b]{2}{*}{ Lantana cultivar } & \multicolumn{4}{|c|}{ Plant rating ${ }^{2}$} & \multicolumn{4}{|c|}{ Flower intensity rating ${ }^{y}$} \\
\hline & & Eval. 1 & Eval. 2 & Eval. 3 & Eval. 4 & Eval. 1 & Eval. 2 & Eval. 3 & Eval. 4 \\
\hline$\overline{\mathrm{Balm}}$ & Bloomify Red & $3.8 \mathrm{ab}$ & $3.8 \mathrm{a}$ & $4.0 \mathrm{a}$ & $3.3 \mathrm{a}$ & $2.5 \mathrm{a}$ & $2.5 \mathrm{a}$ & $4.3 \mathrm{a}$ & $1.0 \mathrm{~b}$ \\
\hline \multirow{2}{*}{ Ft. Pierce } & Bloomify Red & $3.0 \mathrm{~b}$ & $2.0 \mathrm{~b}$ & $3.0 \mathrm{~b}$ & 2.8 & 3.0 & $1.8 \mathrm{~b}$ & 2.8 & $2.0 \mathrm{~b}$ \\
\hline & Pink Caprice & $5.0 \mathrm{a}$ & $4.3 \mathrm{a}$ & $4.0 \mathrm{a}$ & 2.0 & 3.8 & $3.8 \mathrm{a}$ & 4.0 & $3.0 \mathrm{a}$ \\
\hline
\end{tabular}

${ }^{\mathrm{z} P l a n t s}$ were rated on a scale of 1 to 5 , with $1=$ performing very poorly and unacceptable, $3=$ performing fairly and acceptable as ornamental plants, and $5=$ performing outstandingly and highly desirable. Lantana plants were transplanted to ground plants in June 2015. The four evaluations were performed in Aug. (Eval. 1), Sept. (Eval. 2), Oct. (Eval. 3), and Nov. (Eval. 4), 2015, respectively.

${ }^{\mathrm{y}}$ Flower intensity was rated on a scale of 1 to 5 , with $1=0 \%$ to $20 \%, 2=21 \%$ to $40 \%, 3=41 \%$ to $60 \%, 4=61 \%$ to $80 \%$, and $5=81 \%$ to $100 \%$ of the maximum flower coverage of the plant. The four evaluations were performed in Aug. (Eval. 1), Sept. (Eval. 2), Oct. (Eval. 3), and Nov. (Eval. 4), 2015, respectively.

${ }^{\mathrm{x}}$ Means with the same letter within columns within the trial sites are not significantly different by the least significant difference procedure at $P<0.05$. Ns $=$ not significantly different by the Tukey's honestly significant difference procedure at $P<0.05$.

the pollen stainability (or male fertility) of 'UF-1013-1' was reduced by $95 \%$ from that of 'Pink Caprice'.

\section{Female Sterility}

Fruit (seed) production per peduncle and seed germination or seedling emergence are the primary factors determining lantana's female fertility (or sterility) (Czarnecki, 2011; Czarnecki et al., 2012). A female fertility index (FFI) can be derived by multiplying fruit production per peduncle with seed germination and used to compare the female fertility (or sterility) of different lantana cultivars.

Fruit production per peduncle in replicated field trials. Data were collected from the replicated field trials in Balm and Ft. Pierce described earlier. Four data collections were made for each plant at each trial site. In each collection, 20 peduncles were randomly sampled from each plant, and drupes on these peduncles were counted as immature (green) or mature fruit. Thus, in each fruit collection, $\approx 120$ peduncles were sampled for each cultivar trialed in Balm, and $\approx 80$ peduncles were sampled for each cultivar trialed in Ft. Pierce. The four fruit collections in Balm were made on 17 Aug., 14 Sept., 16 Oct., and 18 Nov. 2015, respectively. The fruit collections in Ft. Pierce were conducted on 12 Aug., 10 Sept., 14 Oct., and 11 Nov. 2015, respectively. An ANOVA and separation of mean fruit production values by the Tukey's honestly significant difference procedure were performed using JMP Pro 13.2.0 (SAS Institute) to compare the fruit production of 'UF-1013-1' with that of 'Bloomify Red' and 'Pink Caprice'.
As previously reported by Deng et al. (2017), 'Pink Caprice' produced the largest number of drupes among all the entries in the two replicated trials (Table 3). Each peduncle had an average of 7.941 drupes in Ft. Pierce and 10.313 drupes in Balm, averaged to 9.127 drupes per peduncle across the two sites and four harvests. The number of drupes per peduncle for the sterile cultivar Bloomify Red ranged from 0 to 0.050 and averaged to 0.015 across the two sites over the 4 months. The number of drupes 'UF-1013-1' produced per peduncle ranged from 0 to 0.038 and averaged to 0.009 across two experimental sites and over 4 months (Table 3). This level of fruit production in 'UF-1013-1' represented $>99 \%$ reduction from the fruit production of 'Pink Caprice'.

Seed germination. This was conducted as previously reported (Deng et al., 2017). Mature drupes were collected from each plant in the earlier-described replicated field trials in Balm and Ft. Pierce, FL. Seeds were extracted, cleaned, and air-dried at each test site and germinated at IRREC. Due to having few fruit for 'UF-1013-1' and 'Bloomify Red', fruit from four harvests at each site were combined before seed extraction. Seeds were germinated in transparent polystyrene germination boxes (Hoffman Manufacturing, Corvallis, OR) containing two sheets of germination paper (Anchor Paper Company, St. Paul, MN) moistened with $15 \mathrm{~mL}$ of water. Germination boxes were placed in temperature and light-controlled chambers equipped with cool-white fluorescent lamps (Model 818; Precision Scientific, Winchester, VA). The germination condition was $12 \mathrm{~h}$ light at $25{ }^{\circ} \mathrm{C}$ (photosynthetic photon flux was 22 to $30 \mu \mathrm{mol} \cdot \mathrm{m}^{-2} \cdot \mathrm{s}^{-1}$ at shelf level) followed by $12 \mathrm{~h}$ dark at $15^{\circ} \mathrm{C}$. Germination of seeds was monitored every other day for a period of $60 \mathrm{~d}$. A seed was considered germinated when radicle emergence was $\geq 2.0 \mathrm{~mm}$. Seeds were removed once germination occurred to prevent inaccurate data collection.

A subsample of seeds of 'Pink Caprice' were also sent to a commercial seed testing laboratory (Midwest Seed Services, Brookings, SD) for initial seed viability tests. The distal end of the cotyledon of each seed was cut off and seeds were stained overnight at $30{ }^{\circ} \mathrm{C}$ in $1.0 \%$ tetrazolium $(2,3,5$-triphenyl chloride). Seeds were considered viable if the entire embryo stained evenly. 'UF-1013-1' and 'Bloomify Red' produced few or no seeds at either site and were therefore not subjected to viability tests.

Seeds of 'Pink Caprice' showed an average of $65.0 \%$ viability, germinated readily, with an average germination percentage of $45.0 \%$ in $60 \mathrm{~d}$ (Deng et al., 2017). For 'UF1013-1', three mature drupes were collected from the Ft. Pierce trial over 4 months. Three seeds were extracted, but all were abnormal when visually examined. Thus, there were no seeds from 'UF-1013-1' for seed viability or germination tests.

FFI. The FFI for 'Pink Caprice' was 4.107 (Deng et al., 2017). Because of the lack of seed germination data, it was not possible to calculate the FFI for 'UF-1013-1'. However, on the basis of its triploidy and extremely low fruit production, it was expected that the FFI for 'UF-1013-1' would be close to 0 and similar to that of 'Bloomify Red'. 


\section{Plant Growth, Performance, and Flowering}

As previously reported (Deng et al., 2017), lantana plants grown at the two experimental sites were evaluated for plant performance on a scale of 1 to 5 , with $1=$ few branches, open canopy, lacking vigor; 3 = performing fairly well and acceptably as ornamental plants; and 5 = full plants, dense canopy, desirable shape and color, very attractive. Flower intensity was also rated on a scale of 1 to 5 , with $1=0 \%$ to $20 \%, 2=21 \%$ to $40 \%, 3=41 \%$ to $60 \%, 4=61 \%$ to $80 \%$, and $5=81 \%$ to $100 \%$ of the maximum flower coverage of the plant. At the first 2 months posttransplanting (MPT) and the last evaluation (5 MPT), plant height and width in two directions were measured. On the basis of plant height and width, a plant size index was calculated for each plant in the trials. Data on plant performance, flower intensity, and plant growth were analyzed using the JMP Pro 13.0.2 to determine the significance of differences among cultivars by ANOVA. When differences were significant, mean separation was performed using the Tukey's honestly significant difference procedure.

On average, plants of 'UF-1013-1' grown in Balm were $35.7 \mathrm{~cm}$ tall and $51.6 \mathrm{~cm}$ wide and had a plant size index of $0.076 \mathrm{~m}^{3}$ by 2 MPT (Table 4). By 5 MPT, plants of 'UF-
1013-1' reached an average height of $47.8 \mathrm{~cm}$ and an average width of $86.6 \mathrm{~cm}$ (Table 4). Within 3 months (from 2 MPT to 5 MPT), plants increased height by $33.9 \%$ and width by 67.8\%. Plants of 'UF-1013-1' grown in Ft. Pierce had a similar average height $(47.8 \mathrm{~cm}$ by 5 MPT), width $(76.5 \mathrm{~cm})$ and size index $\left(0.211 \mathrm{~m}^{3}\right)$ with those grown in Balm (Table 4).

As reported previously (Deng et al., 2017), plants of 'Pink Caprice' were vigorous and large. By 2 MPT, plants were $59.5 \mathrm{~cm}$ tall and $103.0 \mathrm{~cm}$ wide, and by $5 \mathrm{MPT}$, they reached an average height of $89.3 \mathrm{~cm}$ and an average width of $211.7 \mathrm{~cm}$. By $2 \mathrm{MPT}$, plants of 'UF-1013-1' were $35.5 \%$ to $40.0 \%$ shorter in height, $49.9 \%$ to $54.4 \%$ narrower in width, and $84.5 \%$ to $86.6 \%$ smaller in size index (Table 4). By 5MPT, plants of 'UF-1013-1' were $46.5 \%$ to $50.5 \%$ shorter in height, $59.1 \%$ to $64.5 \%$ narrower in width, and $90.9 \%$ to $93.8 \%$ smaller in size index than 'Pink Caprice' (Table 4).

Plants of 'UF-1013-1' grown in Balm received 3.0 to 4.7 on plant rating, which were not significantly different from the plant rating scores of 'Bloomify Red' but were significantly higher than the scores of 'Pink Caprice' (Table 5). The flower intensity rating score of 'UF-1013-1' ranged from 1.5 to 3.3, suggesting that 'UF-1013-1' had a lower flower coverage than 'Bloomify Red' in two of the four evaluations and had higher flower

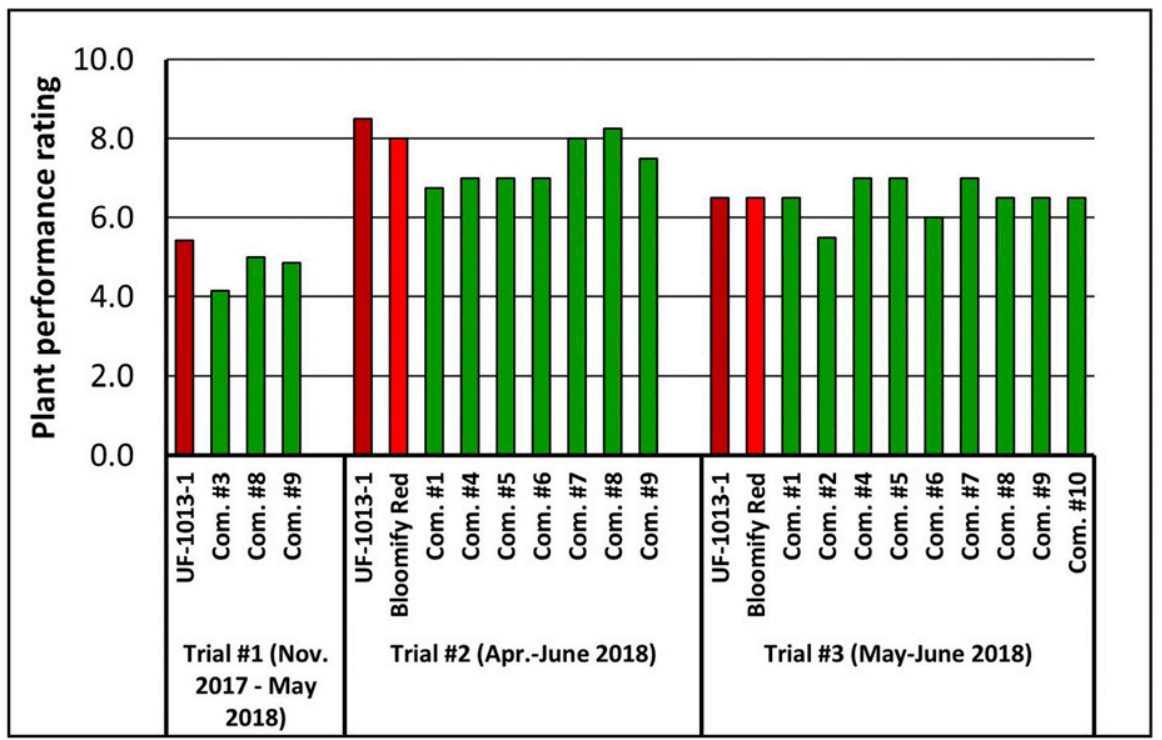

Fig. 3. Overall plant performance ratings of 'UF-1013-1' lantana (L. camara) (solid red bars) compared with 'Bloomify Red' (light red bars) and commercial cultivars (Com. 1 to 10) (green bars) in three field trials in Citra, FL, from Nov. 2017 to June 2018. The trials were not replicated but contained five plants per entry in each trial. Ratings were on a scale of 1 to 10 , with $1=$ poorest, $5=$ acceptable, and $10=$ excellent. Lantana plants were installed on raised ground beds covered with metalized plastic and grown in full sun. coverage than 'Pink Caprice' in three of the four evaluations (Table 5).

Plants of 'UF-1013-1' grown in Ft. Pierce received 2.8 to 3.5 on plant rating and 2.3 to 3.8 on flower intensity rating (Table 5 ). That is, 'UF-1013-1' and 'Bloomify Red' were not significantly different on plant and flower intensity ratings. 'UF-1013-1' received a lower plant rating score than 'Pink Caprice' in two of the four evaluations and a lower flowering intensity rating in one of the four evaluations (Table 5).

In addition, the plant performance of 'UF1013-1' was evaluated in three nonreplicated field trials in Citra, FL, from Nov. 2017 to June 2018 (Fig. 3). 'Bloomify Red' was in two of the trials and two to eight commercial lantana cultivars were present in each of the trials. 'UF-1013-1' received the highest scores in two of the trials and a comparable score in the third trial.

\section{Hybridization Potential with $L$. depressa after Hand Pollinations}

Hand pollination experiments were performed in the greenhouse at GCREC in June and July 2015 to assess the hybridization potential of 'UF-1013-1', as a male or female patent, with $L$. depressa. 'Bloomify Red' and 'Pink Caprice' were included in the hand pollination experiments as sterile and fertile lantana controls, respectively (Deng et al., 2017). Hand pollination was conducted as described by Deng et al. (2017). Plants of L. camara cultivars and $L$. depressa were grown on metal benches in gallon plastic containers filled with a commercial soilless mix (Fafard 3B) amended with a controlled release fertilizer (Osmocote, $15 \mathrm{~N}-3.9 \mathrm{P}-10 \mathrm{~K}, 5$ - to 6 -month release at $21{ }^{\circ} \mathrm{C}$; Scotts) at $7.12 \mathrm{~kg} \cdot \mathrm{m}^{-3}$. The stock plants were arranged into three blocks, and in each block, they were randomly placed on the benches. The experimental unit was two containerized plants. Temperatures inside the greenhouse ranged from a low of $21^{\circ} \mathrm{C}$ at night to a high of $33{ }^{\circ} \mathrm{C}$ during day. No supplemental lighting was provided. Plants were drip-irrigated twice a day. Fresh anthers were collected from mature unopened flowers of male parents and applied immediately to emasculated flowers of female parents. At maturity, fruit produced by the pollinated flowers were collected and counted, and seeds were extracted and sown to determine seedling emergence.

As previously described by Deng et al. (2017), 'Pink Caprice', as a male parent, produced an average of $8.6 \%$ fruit set on $L$. depressa flowers (Table 6). When pollinated with $L$. depressa, 'Pink Caprice' flowers

Table 6. Hybridization potential of 'UF-1013-1' with L. depressa after hand pollinations compared with 'Bloomify Red' (sterile) and 'Pink Caprice' (fertile).

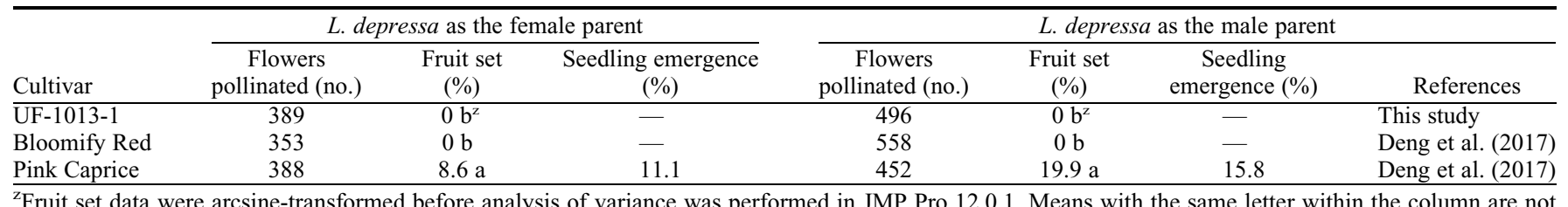

${ }^{\mathrm{z}}$ Fruit set data were arcsine-transformed before analysis of variance was performed in JMP Pro 12.0.1. Means with the same letter within the column are not significantly different by the Tukey's honestly significant difference procedure at $P<0.05$. 
showed 19.9\% fruit set (Table 6). Seeds from crosses between 'Pink Caprice' and $L$. depressa or reciprocal showed $11.1 \%$ or $15.8 \%$ seedling emergence (Table 6). As a male parent, 'Bloomify Red' did not cause any fruit set on $L$. depressa flowers. Nor did it set any fruit after hand pollination with $L$. depressa.

A total of $389 \mathrm{~L}$. depressa flowers were pollinated with 'UF-1013-1', and none of the pollinated flowers set fruit, resulting in $0 \%$ fruit set (Table 6). When 'UF-1013-1' was used as the female parent, it did not set any fruit after it was hand pollinated with $L$. depressa. Thus, 'UF-1013-1' did not hybridize with L. depressa (Table 6). These data confirm the high level of male and female infertility in 'UF-1013-1'.

\section{Conclusion}

Plants of 'UF-1013-1' are of moderate vigor, have an excellent branching habit and form a dense, round canopy. Cuttings produce high-quality flowering plants in small and large containers and perform well in the landscape. Flowers of 'UF-1013-1' are yellow/bright red. These attributes make 'UF-1013-1' a desirable replacement of existing fertile lantana cultivars.

Compared with 'Pink Caprice', a L. camara cultivar that is the closest to the species' resident taxon (wild or naturalized type), the pollen stainability of 'UF-1013-1' has been reduced by at least $95 \%$. This new triploid cultivar did not cause fruit set on $L$. depressa flowers or set any fruit when hand-pollinated with $L$. depressa. Fruit production of this triploid has been reduced by $>99 \%$. Generally 'UF-1013-1' did not produce viable seeds in replicated field trials. The high level of male and female infertility of this triploid was stable from Balm to Ft. Pierce and Citra. These results indicate that 'UF-1013-1' has little potential to hybridize with $L$. depressa and to produce viable interspecific progeny.

\section{Availability}

'UF-1013-1' has been licensed to Proven Winners for commercial production and named Luscious ${ }^{\circledR}$ Red Zone ${ }^{\mathrm{TM}}$. A plant patent will be applied for this lantana cultivar by the Florida Agricultural Experiment Station. Production of this cultivar will need a licensing agreement with the Florida Foundation Seed Producers, Inc. (http:// www.ffsp.net/), P.O. Box 309, Greenwood, FL 32443. Information about plant material and propagation agreement can be obtained from the Florida Foundation Seed Producers, Inc.

\section{Literature Cited}

American Horticultural Society (AHS). 1998. Publications-Heat zone finder. 26 Feb. 2011. <http://www.ahs.org/publications/ heat_zone_finder.htm $>$.

Bachman, G.R. 2018. Reliable lantana blooms in summer landscapes. Growing America. 22 Aug. 2019. <http://www.growingamerica.com/ news/2018/03/reliable-lantana-blooms-summerlandscapes $>$.

Bechtloff, A., C.R. Adams, S.B. Wilson, Z. Deng, and C. Wise. 2019. Insights from Southeastern US nursery growers guide research for sterile ornamental cultivars. J. Environ. Hort. 37(1):918.

Cao, Z., Z. Deng, and M. McLaughlin. 2014. Interspecific genome size and chromosome number variation sheds new light on species classification and evolution of Caladium (Araceae). J. Amer. Soc. Hort. Sci. 49:449459.

Chen, C., C.H. Bock, W.R. Okie, F.G. Gmitter, Jr., S. Jung, D. Main, T.G. Beckman, and B.W. Wood. 2014. Genome-wide characterization and selection of expressed sequence tag simple sequence repeat primers for optimized marker distribution and reliability in peach. Tree Genet. Genomes 10:1271-1279.

Czarnecki, D.M., II. 2011. Genetic sterilization and reproductive biology of Lantana camara. $\mathrm{PhD}$ Diss., Univ. of Fla., Gainesville.

Czarnecki, D.M., II, A. Hershberger, C.D. Robacker, and Z. Deng. 2014. Ploidy level and pollen stainability of Lantana camara cultivars and breeding lines. HortScience 49:1271-1276.

Czarnecki, D.M., II, S.B. Wilson, G.W. Knox, R. Freyre, and Z. Deng. 2012. UF-T3 and UF-T4 Two sterile Lantana camara cultivars. HortScience 47:132-137.

Dehgan, B. and C.L. Guy. 2004. Reproductive biology and invasive potential of Lantana camara. 1 Aug. 2019. <https://portal.nifa.usda. gov/web/crisprojectpages/0191420-reproductivebiology-and-invasive-potential-of-lantana-camaracultivars.html>.

Deng, Z., S.B. Wilson, X. Ying, and D.M Czarnecki. 2017. Infertile Lantana camara cultivars UF-1011-2 and UF-1013A-2A. HortScience 52:652-657.

Doležel, J., J. Greilhuber, and J. Suda. 2007. Estimation of nuclear DNA content in plants using flow cytometry. Nat. Protoc. 2:22332244.

Florida Exotic Pest Plant Council (FLEPPC). 2019. Florida Exotic Pest Plant Council's 2019 list of invasive plant species. 26 Aug. 2019. <http:// fleppc.org/>.

Georgia Exotic Pest Plant Council (GA-LEPPC). 2019. List of non-native invasive plants in Georgia. 22 Aug. 2019. <https://www.gaeppc. org $/$ list/ $>$.

Gong, L. and Z. Deng. 2011. Development and characterization of microsatellite markers for caladiums (Caladium Vent.). Plant Breed. 130(5).

Hammer, R.L. 2004. The Lantana mess-A critical look at the genus in Florida. The Palmetto 23(1):21-23.

Royal Horticultural Society. 1986. RHS Colour Chart. Royal Hort. Soc., London.

Sanders, R.W. 1987. Identity of Lantana depressa and $L$. ovatifolia (Verbenaceae) of Florida and the Bahamas. Syst. Bot. 12:44-60.

Sanders, R.W. 2001. The genera of Verbenaceae in the Southeastern United States. Harv. Pap. Bot. 5:303-358.

Schoellhorn, R. 2004. Lantana-summer color that's tough as nails. GPN-Greenhouse Product News 14(3):14-16. <https://gpnmag. com/article/lantana-summer-color-thats-toughnails/>.

Swearingen J. and C. Bargeron. 2016. Invasive plant atlas of the United States. University of Georgia Center for Invasive Species and Ecosystem Health. 22 Aug. 2019. <http://www.invasiveplantatlas.org/>.

USDA Plant Hardiness Zone Map. 17 Aug. 2019. $<$ https://planthardiness.ars.usda.gov/PHZMWeb/>.

Wirth, F.F., K.J. Davis, and S.B. Wilson. 2004. Florida nursery sales and economic impacts of 14 potentially invasive ornamental plant species. J. Environ. Hort. 22:12-16. 